University of Wollongong

Research Online

Faculty of Commerce - Papers (Archive)

Faculty of Business and Law

2013

\title{
Application of the task-technology fit model to structure and evaluate the adoption of e-books by academics
}

\author{
John D'Ambra \\ University of New South Wales \\ Concepcion S. Wilson \\ University of New South Wales \\ Shahriar Akter \\ University of Wollongong, sakter@uow.edu.au
}

Follow this and additional works at: https://ro.uow.edu.au/commpapers

Part of the Business Commons, and the Social and Behavioral Sciences Commons

\section{Recommended Citation}

D'Ambra, John; Wilson, Concepcion S.; and Akter, Shahriar: Application of the task-technology fit model to structure and evaluate the adoption of e-books by academics 2013, 48-64.

https://ro.uow.edu.au/commpapers/3189

Research Online is the open access institutional repository for the University of Wollongong. For further information contact the UOW Library: research-pubs@uow.edu.au 


\title{
Application of the task-technology fit model to structure and evaluate the adoption of e-books by academics
}

\author{
Abstract \\ Increasingly, e-books are becoming alternatives to print books in academic libraries, thus providing \\ opportunities to assess how well the use of e-books meets the requirements of academics. This study \\ uses the task-technology fit (TTF) model to explore the interrelationships of e-books, the affordances \\ offered by smart readers, the information needs of academics, and the "fit" of technology to tasks as well \\ as performance. We propose that the adoption of e-books will be dependent on how academics perceive \\ the fit of this new medium to the tasks they undertake as well as what added-value functionality is \\ delivered by the information technology that delivers the content. The study used content analysis and an \\ online survey, administered to the faculty in Medicine, Science and Engineering at the University of New \\ South Wales, to identify the attributes of a TTF construct of e-books in academic settings. Using \\ exploratory factor analysis, preliminary findings confirmed annotation, navigation, and output as the core \\ dimensions of the TTF construct. The results of confirmatory factor analysis using partial least squares \\ path modeling supported the overall TTF model in reflecting significant positive impact of task, \\ technology, and individual characteristics on TTF for e-books in academic settings; it also confirmed \\ significant positive impact of TTF on individuals' performance and use, and impact of using e-books on \\ individual performance. Our research makes two contributions: the development of an e-book TTF \\ construct and the testing of that construct in a model validating the efficacy of the TTF framework in \\ measuring perceived fit of e-books to academic tasks.

\section{Keywords} \\ era2015

\section{Disciplines} \\ Business | Social and Behavioral Sciences

\section{Publication Details} \\ D'Ambra, J., Wilson, C. \& Akter, S. (2013). Application of the task-technology fit model to structure and \\ evaluate the adoption of E-books by academics. Journal of the American Society for Information Science \\ and Technology, 64 (1), 48-64.
}




\title{
Application of the Task-Technology Fit (TTF) Model to Structure and Evaluate the Adoption of E-books by Academics
}

\author{
John D’Ambra* and Concepción S. Wilson \\ School of Information Systems, Technology and Management, University of New South Wales, Sydney 2052 \\ NSW, Australia.E-mail: j.dambra@unsw.edu.au, t: +61 2 93854854,f: +61 2 96624061; \\ c.wilson@unsw.edu.au, t: +612 93857134,f: +61296624061 \\ Shahriar Akter \\ School of Management and Marketing, University of Wollongong, NSW 2522, Australia, \\ Email: sakter@uow.edu.au, t: +61242213377 \\ *corresponding author
}

\section{Abstract}

Increasingly e-books are becoming alternatives to print-books in academic libraries, thus providing opportunities to assess how well the use of e-books meet the requirements of academics. This study uses the task-technology fit (TTF) model to explore the inter-relationships of e-books, the affordances offered by smart readers, the information needs of academics, and the "fit” of technology to tasks as well as performance. We propose that the adoption of e-books will be dependent on how academics perceive the fit of this new medium to the tasks they undertake as well as what added-value functionality is delivered and utilized by the information technology that delivers the content. The study used content analysis and an online survey, administered to the faculty in Medicine, Science and Engineering at the University of New South Wales, to identify the attributes of a TTF construct of e-books in academic settings. Using exploratory factor analysis, preliminary findings confirmed annotation, navigation and output as the core dimensions of the TTF construct. The results of confirmatory factor analysis using partial least squares (PLS) path modeling supported the overall TTF model in reflecting significant positive impact of task, technology, and individual characteristics on TTF for e-books in academic settings; it also confirmed significant positive impact of TTF on individual's performance and use, and impact of using e-books on individual performance . Our research makes two contributions: the development of an e-book TTF construct and the testing of that construct in a model validating the efficacy of the TTF framework in measuring perceived fit of e-books to academic tasks.

Keywords: e-books, adoption, task-technology fit, TTF, academics, academic libraries 


\section{Introduction}

The emergence of e-books and e-reader technologies has changed the nature of publishing and the provision of books for both recreational reading and reading as part of the learning process. E-books present several challenges in terms of business models for publishers, retailers, libraries and information services, as well as behavioral changes for readers (Bhattacharjee, Gopal, Marsden, \& Sankaranarayanan, 2011). Implications of ebooks in academic settings are particularly salient as e-books present cost savings both in real terms and in the acquisition, processing and management costs in libraries. As well as offering cost savings, e-readers used to store and display e-books offer significant advantages in mobility, storage, and value-added functionality in terms of searching and manipulating the content.

As e-books are now a real alternative in academic settings, both from a teaching and research perspective, questions arise in terms of the utility offered by e-books and how they meet the needs of academic users. Some research has been conducted on the adoption and use of e-books in academic settings. This corpus of research has been restricted to qualitative and descriptive approaches generally with small to medium sample sizes. Thus there is a gap in the extant literature on e-book adoption, on the effectiveness of e-books as a resource for academics, and the related impact on the perceived performance of e-books in supporting the work of academics. The focus of this paper is to explore the perceptions of the fit of e-books to academic tasks and the perceived impact of the use of e-books on perceived performance. The theoretical lens used is task-technology fit (Goodhue \& Thomson, 1995) which argues that technology needs to be willingly accepted as well as fit well with the users and their corresponding tasks to prove its effectiveness. This study adopts the task-technology fit (TTF) perspective as it is a powerful model to analyze adoption and use behavior of an innovative IT artifact in a specific context (Benbasat \& Barki, 2007). Though TTF has been widely applied in information systems research (Lee, Cheng, \& Cheng, 2007; Zhou, Lu, \& Wang, 2010; Junglas, Abraham, \& Watson, 2008), there is a paucity of research in e-book settings. A review of the literature reveals that the application of TTF in the ebook environment has been under-researched and much of the literature remains largely fragmented and anecdotal. This study adopts TTF as the guiding perspective for developing and validating a multidimensional task-technology fit construct in e-book settings; it is one of the earliest to conceptualize and test a TTF construct to capture users’ perceptions on e-book adoption and use behavior.

One general research question drove this exploratory study: how do users perceive task-technology-fit with regard to e-books at the individual level? In an effort to answer this question, the study developed and validated 
a multidimensional TTF construct by focusing on the extant literature, qualitative findings, and empirical insights. We first consider the changing landscape of the e-book industry identifying the key stakeholders in the academic book sector. We briefly discuss earlier studies of e-text (including e-books and e-textbooks) usage in academic institutions mostly from the Library and Information Science (LIS) literature and the use of the TTF model in Information Systems. We then develop guidelines to establish fit for e-book use by academics; discuss the results and implications of our TTF model for research and practice; and conclude with suggestions for future research.

\section{Background}

\section{The E-book Industry}

Sales figures of e-books demonstrate the impact that the emergence of e-books is having on the publishing industry. In Australia the sale of e-books has increased by over 100\% for the two years 2008 - 2009 (Cox, 2010). In the USA the Association of American Publishers reports that e-book sales increased from $0.6 \%$ of total market share in 2008 to $6.4 \%$ in 2010 . This represents a $1274.1 \%$ increase in net sales revenue with total revenue for 2010 at US\$878 million as e-book unit sales increased by $1039.6 \%$ for the same three-year period (publishers.org/bookstats/formats/). With this exponential growth in the sales of e-books the publishing industry is transforming itself by engaging in new business relationships and business models with industry partners. These new business models are revolutionizing the traditional book trade supply chain. One sector impacted by the e-book revolution is the educational sector (publishing for schools and higher education institutions). In the university domain the traditional model has been that academics prescribe textbooks and students then (generally) purchase them. Academics have been the focus of the marketing efforts of publishers as they are the decision makers regarding what texts are to be used by students. In recent years textbooks have been accompanied by supplementary materials (lecture slides, student workbooks, study guides, and test banks) which are delivered electronically. Academics also use alternatives to textbooks (collections of readings, or customized textbooks) which are now mostly provided electronically to students. E-texts offer new challenges and benefits to consumers and stakeholders in university settings. Figure 1 illustrates the stakeholders in the textbook and e-textbook supply chain. The following section considers the new and emerging relationships between and among the stakeholders.

[FIG 1 about here] 
Students are the final consumers of textbooks. They have limited resources and often do not purchase the textbooks required for their courses. To minimize their costs students often seek substitutes: second hand textbooks; library copies; electronic editions (legal or illegal); or attempt to complete courses without textbooks.

Academics are the key players in the textbook market as they select the textbooks to be used and the format of that text: either print or electronic. As well as prescribing textbooks academics make use of other texts to support their teaching and research. Given their key role, academics have been the focus of publishers' marketing efforts.

Universities are now mediators between publishers and students by entering into collaborations with publishers acquiring rights to collections of e-textbooks (recommended by their academics) and making them available to students for a fee which is passed back to the publishers. Such schemes minimize textbook costs for students and also alleviate the search for substitutes by students. The e-textbooks are made available via learning management systems across the range of devices: desktops/laptops; tablet computers; e-readers; and smart phones. Examples of such schemes are the eText initiative at Indiana University (http://etext.iu.edu_ accessed 18/Mar/2012) and the Internet2, Mc-Graw Hill, and Courseload 2012 eText pilot in five universities: UCBerkeley, Cornell, Minnesota, Virginia and Wisconsin (http://internet2.edu/news/pr/2012.01.18.etextpilot.html).

Publishers are now engaging directly with technology providers and universities providing content through collaboration and/or business agreements. Publishers also make content available to aggregators who in turn offer consolidated content to academic libraries.

Libraries are now faced with a new paradigm in information provision. Implications of e-books and etextbooks in academic libraries is particularly salient as they present cost savings both in real terms and in the acquisition, processing and management costs in libraries. Academic libraries must now grapple with new lending models to their communities.

Technology companies are the providers of the hardware and software that enable e-textbooks. The technology adds value for users in terms of costs, access and functionality. Technology providers are now entering into business agreements with publishers for the provision of e-books and e-textbooks on their devices.

Retailers, "brick and mortar” and online, are morphing into one: brick and mortar retailers have developed their own e-readers (for example, Barnes and Nobles’ Nook and Amazon’s Kindle) to take market share from 
their online competitors. Online retailers are adopting new business models by becoming publishers and entering into exclusive arrangements with authors.

One factor that emerges from the overview above is the key role of the academic. Academics are the decision maker in terms of textbook choice and the drivers of collections in academic libraries. As e-books are now a real alternative in academic settings both from a teaching and research perspective, questions arise in terms of the utility offered by e-texts and how well they meet the needs of academic users. This is the focus of the exploratory study reported in this paper.

\section{LIS Perspective of E-book Adoption}

There is an emerging body of literature in the adoption and use of e-books in academic institutions with Bennett and Landoni (2005) setting the background for how the stakeholders of the e-book industry can progress the adoption of the 'new' technology. In analyzing a sample of 101 academics and students, Anuradha and Usha (2006) found the use of academic e-books to be low indicating a need for creating awareness and user education about the software and hardware nature of e-books. Woody, Daniel, and Baker (2010) in a survey of 91 students found that participants who had previously used e-books preferred print-texts for learning. Bierman, Ortega, and Rupp-Serrana (2010) in a qualitative study of pure and applied science academics found no significant difference in the way that e-books were utilized. Respondents indicated that convenience is a significant driver and that e-books should emulate the use and functionality of perusing content on the Web (e.g., readability, minimum scrolling and clicking, integration of multimedia, hyperlinking, consistency in lookand-feel, ability to manipulate and print text and graphics). In a further qualitative study of geoscience academics and graduate students, Foote and Rupp-Serrano (2010) found that discipline-specific issues are significant in the adoption and viability of e-books. These issues include: requirements for high quality graphics; ability to export graphics to other software and to manipulate graphics; need for three-dimensional graphics; facility for multimedia; ease of outputting in various formats (.pdf, html); provision of hyperlinks; and customization of content. Shelburne (2009) reports on a collaboration between the University of Illinois and Springer Publishing where 1,547 academics and students responded to a survey of closed and opened questions. An important output of the study is the consolidation of comments on e-book advantages and disadvantages. Advantages were described as: accessibility, searchability, portability and environmental sustainability. Disadvantages include: on-screen reading, navigation issues, searching issues, and Digital Rights Management issues. Foote and Rupp-Serrano (2010) also report advantages and disadvantages of e-books with a somewhat different perspective. In term of advantages, academic users found e-books: useful for initial research; good for 
fact checking; capable of linking to a course management system; and provided cost savings for students.

Academics also acknowledged that personal print-books will not disappear, while students noted the potential cost savings. For disadvantages, academics reported: battery life issues; a preference for p-books if regular reference is required; and a preference for classic texts in print. Students were concerned with copyright issues; a dislike of on-screen advertising; and possible increase in student fees with rising technology usage. The largest study of e-books is the National e-books Observatory (NeBO) project reported by Jamali, Nicholas, and Rowlands (2009) where an analysis of 16,000 free text answers to two open-ended questions about e-books contained in a UK national survey conducted in 2008 is reported. Advantages identified by $81 \%$ of the respondents include: online access, searchability and cost. Disadvantages include: difficulties in reading from the screen; issues with printing selected pages of e-books easily; and saving in a preferred format (.pdf). Data from the same NeBO funded project showed that e-textbooks were used primarily "for obtaining snippets of information and fact finding” by thousands of business and management students. Additionally, "power browsing” of multiple e-textbooks suggested that the interactive features and searching capabilities of etextbooks were highly valued by students (Nicholas, Rowlands, \& Jamali, 2010).

A survey by Library Journal (2011) showed that nearly all 488 responding academic libraries offered ebooks with $13 \%$ subscribing or owning $\geq 100,000$ e-books. Some of the barriers to the use and adoption of ebooks by academics are: awareness of availability; limited interactivity; limited or no downloading availability; complex Digital Rights Management (DRM) practices; limited or no concurrent users or check-outs permitted; and lack of standard e-book interfaces. From an e-learning perspective, Keller (2012) used the social psychology affective model of "attitude influence" upon reading to explore the behavior of undergraduate students when choosing to read texts "in print or on screen". Although choices of reading were dictated mainly by document type (e.g., long text in print and reference books on screen), an important reason for preferring printed text was the distraction caused by computers.

\section{Information Systems Perspective of E-book Adoption}

Unlike e-journals that are now integrated into the information seeking behavior of academics (McClanahan, Wu, Tenopir, \& King, 2010; Nicholas, Williams, Rowlands, \& Jamali, 2010), e-texts are still an emerging technology with some major barriers including preference of print-texts for 'long-form reading' (Library Journal, 2011). Interestingly McClanahan et al., although discovering that e-journals have supplanted their printed counterparts, academics nonetheless preferred printing selected papers for reading once downloaded. We propose then that to some extent adoption of e-books will be dependent on how academics perceive the "fit" of 
this new medium to the tasks they undertake as well as what added-value functionality is delivered and utilized by the information technology that deliver the content.

Task-technology fit (TTF) is an established theoretical framework in information systems research that enables the investigation of issues of fit of technology to tasks as well as performance. One significant focus of TTF has been on individuals to assess and explain information systems success and impact on individual performance (Goodhue \& Thompson, 1995). Goodhue and Thompson propose the technology-to-performance chain where characteristics of IT, tasks, and individual users explain information system use and individual performance. Empirical results suggested that TTF and usage together better explain the impact of IT on individual task performance than usage alone. Further studies have demonstrated the efficacy of the TTF construct to measure the value of an information technology (Goodhue \& Thompson, 1995) and to predict performance (Goodhue, Klein, \& March, 2000). TTF relationships can inform the associations between tasks and technology use from a number of perspectives: improved performance (Carswell, Thomas, Petre, Price, \& Richards, 2000); altered user perceptions (Wenger \& Carlson, 1995) or increased user utilization (Kim \& Malhotra, 2005; Ngai, Poon, \& Chan, 2007; Venkatesh, Morris, Davis, \& Davis, 2003). From an education perspective, McGill, Klobas, and Renzi (2011) used the TTF model to demonstrate "that the better the fit of an LMS [learning management system] to the skills of an instructor and the tasks that the instructor must complete, the more positive its effect on their performance is likely to be”. Raven, Leeds, and Cho (2010) applied a TTF model to the use of digital video tools for oral presentation in the classroom; they found "a significant fit between digital video tools (technology) and improvement of oral presentation skills (task)”. The TTF construct is therefore concerned with the extent to which technology meets task-related requirements - a construct that is conceptually related to the TAM (Technology acceptance model) construct of user-perceived usefulness. TTF can offer guidance for the design of a technology or task. TTF explores the relationship between individual tasks and technology fit profiles by measuring user performance and technology utilization. The exploration of the connection between tasks and technology has been useful and warrants continued use (Barki, Tiliah, \& Boffo, 2007). 


\section{Methodology}

\section{Modeling TTF for E-books}

The investigative approach proposed in this paper is a novel one within the context of the extant literature. As part of the justification of the approach we contrast the previous relevant research on e-book use against the approach taken in this paper.

Table 1 outlines the relevant research on e-book use. The column "Focus" considers the main purpose of the studies; the "Approach" column considers the methods used in terms of quantitative or qualitative; "Unit of analysis” indicates the population studied; the sample size and findings of each study are provided in the last two columns. Overwhelmingly the focus of previous research has been on usage and preference. The majority of the studies offer findings in terms of preferences and perceived advantages and disadvantages of e-books. The approach of the studies is mixed, with some studies using both qualitative and quantitative methods. Interestingly, all the quantitative studies are descriptive with none investigating or using a causal model. As discussed below we consider e-books to be an information system and, therefore, can be evaluated using theoretical approaches from the Information Systems domain. The focus of the current research is measuring and evaluating the perceived "fit" of e-books to the tasks of academics and investigating the relationship between fit and two other variables: use and performance in a causal model. Parsimoniously the studies in Table 1 have also measured analogues of fit and use: preference for e-books and perceived advantages and disadvantages of e-books. However, to the knowledge of the authors, the current research is the first to present a causal model within a theoretical framework. E-books is an emerging technology, as evidenced by the evolving research approaches outlined in Table 1; however, the use of e-books has now reached a level of accessibility and penetration that calls for evaluation within an information technology framework; thus the approach taken in this study.

\section{[TABLE 1 about here]}

Given the accessibility of e-books on e-readers, tablet computers and smartphones (mobile devices) there are now attributes of the IT artifact (mobile devices) as well as the ability to manage the content and its presentation that must be considered in evaluating the use of e-books on mobile devices. E-books have moved beyond the limited perspective that is evident in the extant research. Thus we present a comprehensive model of e-book usage which is representative of the current utilization context of e-books. 
Various theoretical approaches for evaluating information technology (IT) innovations have been published and utilized in the Information Systems domain (see Table 2). Due to space limitations the efficacy of these approaches for evaluating e-books cannot be discussed here. However two widely accepted theories will be considered: The Technology Acceptance Model (TAM) and The Task-Technology Fit (TTF) model.

\section{[TABLE 2 about here]}

Of the models that have been proposed and examined for user acceptance of IT, TAM is arguably the most widely accepted (King \& He, 2006; Williams, Dwivedi, Lal, \& Schwarz, 2009). TAM has been examined for the causal relationships between task, human, or organizational characteristics by researchers in several Internetbased technology products, environment, and services. This includes e-commerce (e.g.,Ha \& Stoel, 2009), the World Wide Web (e.g., Vijayasarathy, 2004), online service (e.g., Cho, 2006), Internet banking (e.g., Cheng, Lam, \& Yeung, 2006; Lee, 2009), mobile technology (e.g., Schierz, Schilke, \& Wirtz, 2010) and Open Source Software (OSS) (e.g., Gwebu \& Wang, 2011). Overall, most of these studies provided strong evidence to support TAM for predicting system usage behaviour.

As the importance of individual characteristics is stressed, some variables have been suggested to extend the original TAM (Kown \& Wen, 2010). New external variables and perceived constructs have been extended to TAM according to the specific characteristics of the technology, such as individual, task and system characteristics. Moreover, some researchers argued that basic models might not be sufficient to explain the adoption and use of diverse types of technologies and service where specific features of the technology might play a significant role (Mallat, 2007).Thus, it is important to add some explanatory variables into TAM. King and He (2006) defined four main categories for external factors to be extended to the core TAM model. These factors include the following:

- $\quad$ Prior factors (or the inclusion of external precursors), such as situational involvement, personal computer self efficacy and prior usage or experience

- $\quad$ Factors suggested by other theories, such as task-technology fit, trust and risk

- Contextual factors, such as gender, culture and technology characteristics that may have moderator effects

- $\quad$ Consequence factors, such as attitude, perceptual usage, and actual usage.

The TTF model attempts to solve limitations deemed as the major weakness of TAM (Dishaw \& Strong, 1999). A weakness of TAM for understanding IT utilization is its lack of task focus. IT is a tool by which the user completes his/her tasks. Thus, because of the lack of task focus in evaluating IT and its use, performance 
and acceptance contributes to the varied results in IT evaluations (Goodhue \& Thompson, 1995). While the concept of TAM's usefulness consists of tasks, the addition of more task characteristics could provide a better model of IT utilization. The TTF viewpoint addresses this problem (Dishaw \& Strong, 1999). Accordingly, even though TTF is not as well developed as TAM, TTF is a significant user evaluation construct in understanding and predicting the utilization of a particular technology.

In this explanatory work we propose that TTF is an appropriate construct to apply to the tasks of academics supported by e-books whereby we consider task performance as a proxy of IT success - the IT being the use of e-books on an e-reader. E-books on mobile devices take reading books to a new dimension: online e-readers offer the readers of e-books the added functionality of accessing multiple information resources such as online dictionaries, online encyclopedias, and other useful resources. By enabling web access while reading e-books the learning experience is improved, allowing the user to resolve questions and thereby enhance learning while reading. This new context of reading and learning takes the content of books beyond the boundary of print books to an information system capable of resolving information need as it arises in the learning process of reading. Thus we propose that to evaluate e-books as an information resource for academics, the use of theoretical, nomological models used to evaluate information systems are called for. We propose to develop a construct of fit by drawing on qualitative data collected from both users and non-users of e-books. This exploratory, multi-dimensional TTF construct will then be applied to the tasks of academics to consider the effect of fit (and usage) on performance. We first describe the main constructs and then outline the steps to derive TTF for e-books. Table 3 provides an overview of the research model.

[TABLE 3 about here]

\section{Task}

In the broad TTF perspective, tasks are defined as actions carried out by individuals in turning inputs to outputs to satisfy their information needs (Goodhue \& Thompson, 1995). Task characteristics are those that a user might use information technology to perform. Tasks can vary in a number of dimensions: task nonroutineness, task interdependence, and time criticality. In previous operationalization of the TTF approach researchers have used different dimensions and contexts of tasks to measure the task construct: non-routineness and interdependence (Goodhue \& Thompson, 1995; Goodhue, 1995); data file access, quantitative analysis, text and document organization, and literature searches (Goodhue, Littlefield, \& Straub, 1997); tasks varying in structure (Shirani, Tafti, \& Affisco, 1999); a series of managerial questions (Goodhue, Klein, \& March, 2000); communications requirements/centrality (Belanger, Collins, \& Cheney, 2001); non-work based information 
tasks (D’Ambra \& Rice, 2001); Web usage to resolve uncertainty for personal travel (D’Ambra \& Wilson, 2004); planning, knowledge building, diagnosis, and modification (Dishaw \& Strong, 1998; 2003). Not only do tasks vary in terms of routineness, interdependence and time criticality but tasks that are supported by IT occur in multiple contexts within organization and non-organizational contexts and within work and non-work contexts. The proposition being that as tasks become more demanding or the information technology offers less functionality, users' evaluation of TTF of the information technology will decrease. In this exploratory study we construct the task as the activities that academics engage in as part of their teaching and research for which they use the content of books as an information resource.

H1: Task has a positive impact on TTF in e-books.

\section{Technology}

Technology is the tool (hardware, software, data) used by academics in carrying out their teaching and research tasks. The attributes of these technologies can effect usage and users perception of the technology. The TTF model considers the importance of fitting the functionality and attributes of technology used to the demands imposed by individual needs. Research suggests that a better fit will improve perceived performance (Carswell, et al., 2000; Carswell \& Venkatesh, 2002; Goodhue, 1998; McGill \& Klobas, 2009; Zigurs \& Khazanchi, 2008). We construct technology attributes as those that users consider as critical in the usability of a portable reading device. We have developed two dimensions for this construct: Platform and Content. Platform consists of the hardware attributes: weight, size, screen size, etc.; while content consists of the functionality of the software installed on the devices.

\section{H2: Technology has a positive impact on TTF in e-books.}

\section{Individual}

The role of the individual in the use of IT has played a significant part in the study of IT use and adoption. Nan (2011) in a critical review of the literature on IT use identifies four essential attributes of the IT use construct: IT use, IT use behavior, IT use processes, and time. The IT use factor involves users, IT artifacts, and work activities as its key elements. The TTF perspective of IT use and users examines the correspondence between task requirements, individual abilities, and the functionality of an IT system. It highlights the importance of the alignment between the three aspects in inducing positive IT-enabled performance (Nan, 2011). It is a fundamental proposition of the current research that e-books in the context of their use on smart devices are analogous to an IT systems and that certain attributes of the users of e-books may affect the 
perceived fit of the e-books in meeting the task related needs of the user. The evaluation of the fit of a technology and perceptions of performance may vary depending upon the abilities of an individual: experience in the usage of computers and mobile devices and related software; and experience and training in information skills.

H3: Individual's attributes have a positive impact on TTF in e-books.

\section{TTF (Task-Technology Fit): impact on performance and utilization of e-books}

Goodhue and Thompson (1995) indicated that individuals' interactions with an information system are often intertwined with their task-technology individual-adoption behaviors. TTF is measured by assessing how satisfactorily the system function meets the individual task needs; this is so in the current research.

TTF is the relationship between task requirements, individual abilities, and the functionality of the mobile device and its software. Further TTF has been linked to the criterion of personal performance, which can be used in the larger context of considering the impact of information technology on individual performance (Fuller \& Dennis, 2009; Zigurs \& Khazanchi, 2008). Previous research has identified varying approaches to conceptualize fit between available IT functionality and the functionality required to complete various tasks. In developing the current approach to TTF we are guided by the approach of Zigurs and Buckland (1998) and Zigurs, Buckland, Connolly, and Wilson (1999). Zigurs et al. adopted a systematic approach to determine TTF as predefined profiles of inherently consistent characteristics, assuming that fit between academics' tasks and ereaders has a positive impact on task performance and therefore on system success. A qualitative approach was used to determine the dimensionality of the fit construct and is outlined in the Instrument Development section below.

\section{Performance}

Performance is the accomplishment of a portfolio of tasks by an individual. High performance implies a high level of task-technology fit, and satisfaction with the IT (Goodhue \& Thompson, 1995). High TTF increases the performance impact of the system. Academics use books to inform and support their teaching and research. Teaching and research can be enhanced by the resources and knowledge that can be harvested through the use of books. Books therefore are a resource used by academics that do contribute to their success as teachers and researchers. Books have been a traditional resource used by academics free from any information technology context, apart from the use of IT to support the storage and dissemination of material. This context is now changing with the emergence of e-books. E-books offer the same content as print-books but at the same time deliver additional value not possible with print-books due to the technological platform that delivers e- 
books and related content. This new context changes the interaction between academics and the books they use; the impact of this change on performance is yet to be determined.

H4: TTF in e-books has a positive impact on individual performance.

\section{Utilization}

Goodhue and Thompson (1995) presented precursors of utilization which included beliefs of using a system. They argued that TTF should be one determinate of beliefs about the usefulness and importance of a system and the advantages gained from using a system. In the current research, utilization is the use of e-readers and other mobile devices by academics. As use of e-readers (to read e-books) is discretionary, usage must be considered. The better the fit between the capabilities of e-books, the task, and the individual, the more positive the expected consequences and the higher the user's affect towards using e-books. At any given level of utilization greater than zero, a technology with higher TTF will give a better performance. Therefore, performance will be a function of both utilization and TTF (Goodhue \& Thompson, 1995).

H5: TTF in e-books has a positive impact on using e-books.

H6: Utilization of e-books has a positive impact on individual's performance.

The pivotal construct of the technology-to-performance chain is TTF (Figure 2). To the knowledge of the authors no attempt has been made to determine the dimensionality of the TTF construct for the use of e-books in academic settings. One proposition of this paper is that a TTF construct for the use of e-books for academic tasks can be determined.

[FIG. 2 about here]

\section{Instrument Development}

A qualitative approach was undertaken to identify candidate items that may constitute the proposed TTF construct and the technology construct. Two main sources providing artifacts of perceptions of the attributes of e-books were utilized: Shelburne (2009) and Gray and Byrne (2011). Shelburne collected answers to openended questions on the perceived advantages and disadvantages of e-books while Gray and Byrne collected perceptions on the use of e-content on mobile devices from 100 academics. Gray and Byrne provide 144 comments; Shelburne provides 15.

The comments were analyzed using ex post facto content categories. The items that emerged from the content analysis identify candidate attributes of "fit" from the contributors to the two source artifacts. The answers were synthesized and sorted into three different categories (e.g., 'highlight or bookmark contents', 
'browse or search contents' and 'copy or print contents') to identify various dimensions of task-technology fit. In the qualitative study, task-technology fit was frequently identified as a multidimensional and hierarchical construct. Users expressed their perceptions on the attributes of e-books (e.g., "Within an e-book I would like to be able to bookmark" or, "Within an e-book I would like to be able to browse the index," or, "Within an e-book I would like to be able to print”) to match their tasks. Though these attributes were extracted from exploratory research findings, the study consulted the extant literature to refine and improve the overall findings on the tasktechnology fit construct. Duplicate items were dropped, and items reworded to reflect common issues. Finally, an item pool of 20 items was created for the task-technology fit construct after a rigorous reevaluation of the existing items and addition of new items to adjust the context for the current study.

Following the identification of the 20 items the construct validity was assessed by ensuring domain coverage for the task-technology fit construct. Domain coverage was assessed with the help of a panel of five judges, who confirmed the items of the task-technology fit construct. This technique also indicated the degree of "correct" inclusion of items within the target construct, which provided adequate evidence of construct validity. Items that were perceived as confusing or redundant were removed. The selection process finally resulted in 12 items for the overall task-technology fit construct (see Table 4).

[TABLE 4 about here]

For the performance construct we were guided by the work of Torkzadeh and Doll (1999) and included questions on productivity, quality, work completion, and improving performance (see table 3). For the technology construct (platform and content) Gray and Byrne (2011) also collected data on physical attributes of mobile devices used for reading e-books and software functionality of those devices. Those items that were ranked highly in Gray and Byrne (2011) have been used here to measure the technology construct. TTF, performance, and utilization were measured as reflective constructs while technology and individual were measured as formative constructs.

For the purpose of the study and to orientate respondents, we defined e-books as "the electronic equivalent of a printed book converted into digital format which can be displayed on a computer through network services and/or read on a personal computer or handheld device known as e-book readers. Often using specialized proprietary software, e-books may include specific features such as embedded hyperlinks, bookmarks, annotation, text searching, cross reference functions and linking complex multimedia objects.” (adapted from Anuradha \& Usha, 2006).

\section{Sampling}


A pretest with a convenience sample of 21 was undertaken to ensure that (a) the question content, wording, sequence, format and layout, (b) the question difficulty, instructions and (c) the range of the scale (5-point vs. 7point) were appropriate. Based on responses from the pretest, we made context-specific adjustments to refine the final version of the questionnaire.

In order to obtain a probability-based sample, simple random sampling was applied so that each sample unit/element had an equal chance of being selected. The population was defined as the users who had experience of using e-books in the past 12 months. The main survey was undertaken in July 2011; it was administered to the academics in the Faculties of Medicine, Science, and Engineering at the same university where the pilot study was conducted; the sample size of the three Faculties was 4,383. An incentive to enter a draw to win an iPad 2 was offered. There were 434 responses for an initial response rate of nearly 10\%; of the 434 responses, 361 were usable giving a final response rate of 8.2\%. (A question-by-question analysis of the online survey including correlations among the three Faculties will be reported in a forthcoming paper.) The demographic profile of the respondents represents a diverse cross section of staff in academic settings (see Table 5). The respondent group were comprised of 59\% male, nearly $38 \%$ were full time academics, $69 \%$ had more than four years experience in academic settings and almost $84 \%$ had more than five years experience of using e-resources. Respondents represented different academic ranks (e.g., Professor to Associate Lecturer) within the three Faculties.

[TABLE 5 about here]

\section{Results and Analysis}

\section{Measurement Analysis of TTF Construct}

As a major contribution of the current research is to develop a valid TTF construct to evaluate the use of ebooks in academic settings, we first consider the development of the TTF construct, its dimensionality and validity. We conducted factor analysis with varimax rotation to assess the initial measurement scale. The KaiserMeyer-Olkin (KMO) and Bartlett's test of sphericity were used to evaluate the appropriateness of factor analysis. KMO ensured overall measure of sampling adequacy as $0.814(>0.50)$ and the Bartlett’s test provided support for the validity of the instrument at 1723.066 , $\mathrm{df}=66$, significant at $\mathrm{P}=0.000$. Three factors with eigenvalues greater than 1 were extracted (4.462, 1.633 and 1.369). The sums of squared loadings from the three components have a cumulative value of 62.20 percent in explaining the total variance in the data. 
As shown in Table 6, an exploratory factor analysis of the 12 items with a varimax rotation yielded three factors based on an eigenvalue cut off $>1$. The items loaded on three factors: annotation (TTF1, TTF2, TTF3), navigation (TTF4, TTF5, TTF6, TTF7, TTF8) and output (TTF9, TTF10, TTF11, TTF12) under an overall tasktechnology fit construct.

[TABLE 6 about here]

Table 7 shows reliability analysis (Cronbach’s alpha) of the extracted three factors, which exceeded the cut off value 0.60 . Further scale refinement was done by examining corrected item-total correlation to improve the reliability of the three factors. As a result, TTF10 and TTF12 were deleted from the output factors due to low item total correlations. In summary, the initial instrument was refined by retaining 10 items for TTF construct in which annotation contains 3 items, navigation contains 5 items and output contains 2 items.

[TABLE 7 about here]

The remaining 10 items were retained for the next run of factor analysis. As shown in Table 8, an exploratory factor analysis with a varimax rotation yielded three factors based on an eigenvalue cut off of 1 . The refined model explained $69.479 \%$ of the cumulative variance. The remaining items were confirmed into three factors: annotation, navigation and output. Both the KMO (0.793) and the Bartlett's test of sphericity $(\mathrm{p}=$ 0.000) were significant. The minimum Cronbach's alpha was 0.686 for the output construct, satisfying a minimum requirement of 0.60 . The minimum corrected-item-total correlation was 0.523 , exceeding the cut off value of 0.40 recommended by Straub, Boudreau and Gefen (2004). Thus, the reliability of the TTF construct was established. Next, the study conducted confirmatory factor analysis of the overall research model.

[TABLE 8 about here]

\section{Evaluation of the Overall Measurement Model}

The study conducted confirmatory factor analysis (CFA) to check the properties of the overall measurement model in terms of reliability, convergent validity and discriminant validity. In order to assess the overall model, we used Partial Least Square (PLS) Graph 3.0 (Chin, 2001) to estimate the parameters in the outer and inner model. In this case, we applied PLS path modeling with a path weighting scheme for the inside approximation (Chin, 1998; Tenenhaus, Vinzi, Chatelin, \& Lauro, 2005; Wetzels, Odekerken-Schroder, \& van Oppen, 2009). Then we applied nonparametric bootstrapping (Chin, 1998; Efron \& Tibshirani, 1993; Tenenhaus, Vinzi, Chatelin, \& Lauro, 2005; Wetzels, Odekerken-Schroder, \& van Oppen, 2009) with 722 replications (as n=361) to obtain the standard errors of the estimates. 
As shown in the Table 9, the results of CFA show that item loadings of all the reflective constructs were larger than 0.7 and significant at $\mathrm{P}<0.01$. All average variance extracted (AVEs) and composite reliabilities (CRs) exceeded the cut off values of 0.5 and 0.7 respectively. Thus, we ensured convergent validity as all the reflective indicators load much higher on their hypothesized factor than on other factors (own loading are higher than cross loadings). In the case of formative constructs (i.e., technology and individual characteristics), we examined factor weights, instead of factor loadings, which represent the contribution of each indicator to the respective construct (Chin, 2010). Also shown in Table 9, the formative items significantly contribute to their respective constructs as they are significant at $\mathrm{p}<0.05$ (Chin, 1998). We then assessed potential mulitcollinearity among the formative items and the results showed minimum collinearity with the variance inflation factor (VIF) of all items ranging between 1.050 and 1.442.

[TABLE 9 about here]

Additionally, in Table 10, we calculated the square root of the AVEs that exceed the intercorrelations of the construct with the other constructs, which ensures discriminant validity. Thus, the measurement model was considered satisfactory with the evidence of adequate reliability, convergent validity and discriminant validity.This study also estimates the parameters of TTF construct as a second order model. Here, TTF is reflected by annotation $(\beta=0.776)$, navigation $(\beta=0.914)$, and output $(\beta=0.615)$ constructs, which explained 78\%, 91\% and 62\% of overall TTF variance respectively (Appendix 1). Navigation had the greatest reflection of overall TTF construct, followed by annotation and output. The study also estimates the parameters of technology construct as a second-order model. Technology is reflected by platform quality $(\beta=0.852)$ and content quality $(\beta=0.850)$, which explained $73 \%$ and $72 \%$ overall technology variance respectively (Appendix 1). All the path coefficients from TTF and technology constructs to their components are significant at $\mathrm{P}<0.001$ (Appendix 1). Thus, the study confirmed the measurement properties of the research model which could now be used to test the hypotheses and measure the nomological validity of the overall model.

[TABLE 10 about here]

\section{Structural Model}

The standardized solution estimated by PLS (see Figure 3) was used to interpret the structural relation results. Figure 3 shows that the $r^{2}$ and the path coefficients (and significance) provide support for the proposed model. The model explains a substantial portion of the variance of the performance construct, $50 \%$. The variance for TTF and use are $18 \%$ and $7 \%$ respectively. All six causal paths are specified in the proposed model 
and all are statistically significant $(\mathrm{p}<0.005)$ (see Appendix 1 ). These paths reflect the significant positive impact of task (H1), technology (H2), and individual (H3) characteristics on TTF for e-books in academic settings. The results confirm the significant impact of TTF on individual's performance (H4) and use (H5). The findings also confirm the positive impact of using e-books on individual performance (H6). Overall, the tasktechnology fit model was employed to explore its predictive power in terms of the use of e-books by academics. The paths indicated in the model are all significant in terms of the direct and indirect effects of the TTF of ebooks: the entire model accounts for $50 \%$ of the variance of perceived performance in achieving academic tasks; this demonstrates the efficacy of the model. Our results indicate that the task-technology performance chain is a suitable theoretical framework for assessing the adoption of e-books by Australian academics.

[FIG. 3 about here]

Based on the existing TTF literature, the direct effects of antecedents on the e-books TTF (task, technology and individual) were examined. As predicted, task (0.223), technology (0.287) and individual (0.170) had a significant influence on e-books; TTF accounted for $18 \%$ of the variance in TTF (see Figure 3). These results are consistent with those of previous studies (Barki, Titah, \& Boffo, 2007; Dishaw \& Strong, 1999; Goodhue \& Thompson, 1995; McGill \& Klobas, 2009; Staples \& Seddon, 2004).

The impact of TTF on use and performance was significant. Use to performance is a particularly strong relationship $(\beta=0.656)$, while TTF to performance $(\beta=0.140)$ and use $(\beta=0.269)$ were also significant (see Figure 3). These finding reinforce the status of use as an important construct in information systems research in the investigation of adoption, acceptance and diffusion (Barki, Titah, \& Boffo, 2007).

\section{Discussion and Conclusion}

The exploratory research reported in this paper has sought to answer questions regarding the adoption of ebooks by academics and how academics perceive the fit of the functionality of e-books on e-readers and other mobile devices to their main tasks of teaching and research. In answering these questions the paper makes a number of contributions:

- Extending the extant research in evaluating e-books by developing a nomological model incorporating a wide number of factors that constitute the current context of e-book use.

- The development and validation of an e-book task-technology fit construct in a model validating the efficacy of the task-technology fit model in measuring perceived fit of e-books to academic tasks. 
- The findings confirm that the task of academics, technology characteristics, and individual characteristics significantly influence e-books task-technology fit, which again influences an academic's use of e-books and overall performance. However, the findings indicate that further research is required in identifying additional dimensions of fit.

The research has taken a triangulation approach in developing scales for measuring the "fit" of e-books to the needs of academics. This exploratory work demonstrates that it is possible to develop preliminary scales for measuring the TTF of e-books and that such a scale is multidimensional. The factors that have been identified by this research may be of interest to other researchers and information providers concerned with the evaluation and use of e-books. Based on the qualitative findings, supporting literature and factor structure of TTF in this exploratory study, a conceptual model of task-technology fit construct is proposed in Figure 2. We specify TTF construct as a higher-order, reflective construct which is comprised of three dimensions: annotation, navigation and output. We argue that these dimensions are reflections of TTF. We adopt this higher-order reflective modeling perspective as all the indicators in the research model share a common theme and dropping an indicator should not alter the conceptual domain of the construct. The correlation between any two measures is expected to be highly positive and internal consistency is important for such reflective constructs. Furthermore, such reflective measures are expected to be unidimensional; therefore, individual measures can be removed to improve construct validity without affecting content validity.

The items identified in the factors are derived from and consistent with the contextual model discussed in the extant literature. A meta-analysis of the literature outlined above results in the emergence of several themes reflecting the perceived affordances of e-books. We have grouped the themes as follows:

\begin{tabular}{|l|l|l|l|}
\hline \multicolumn{1}{|c|}{ Output } & \multicolumn{1}{|c|}{ Navigation } & \multicolumn{1}{c|}{ Access } & \multicolumn{1}{c|}{ Other } \\
\hline $\begin{array}{l}\text { Readability } \\
\text { Quality graphics } \\
\text { Export/output/printing }\end{array}$ & $\begin{array}{l}\text { Searchability } \\
\text { Emulate web content }\end{array}$ & $\begin{array}{l}\text { Battery life } \\
\text { Portability }\end{array}$ & $\begin{array}{l}\text { Sustainability } \\
\text { Copyright (DRM) } \\
\text { Cost issues }\end{array}$ \\
\hline
\end{tabular}

The current research is consistent with the literature in suggesting that navigation and output are perceptions of factors of the fit of e-books to academic tasks as well as the additional factor of annotation.

The annotation factor is suggestive of the need to interact with the text. The activities of highlighting text, annotating by adding notes, and book marking are related to the need for referencing the text in the future and 
facilitating access to relevant content quickly. The navigation factor reflects the need to search a reference text rather than reading it cover-to-cover. Textbooks are not often read cover-to-cover but are used as a reference with content being used selectively. Therefore navigation or searchability is a critical need. In the context of this study the output factor is interesting. The two items that load highly are related to language: a read-aloud option and translating to another language. Although related to language the two items are quite disparate. The readaloud item suggests that users may wish to engage in multi-tasking while using e-books, particularly with the ability to listen rather than read; while translating to another language may suggest that some users may increase understanding by translating the text or enabling improved access to content for users whose first language is not English.

More broadly this study encompasses academics’ interactions with e-books in terms of accomplishing tasks and investigates the causal relationship between task characteristics, individual characteristics, TTF, utilization, and impact on performance. A key benefit of this study is that we now have an empirical model for assessing and evaluating the adoption of e-books in academic settings; thus, supplementing the results of questionnaires, interviews and other techniques for studying user behavior. E-books are a new medium offering content within a new interactive context. This new interactive context is not just limited to digital media interactions bounded by the e-book itself but to integrating the act of reading into a broad range of activities utilizing additional resources seamlessly through interaction with the WWW and other information technologies/resources. By adopting e-books the behavior of academics will change and it is not yet understood what impact that change will have on outcomes. Of course the adoption of e-books is volitional however the pressure of lower cost models for institutions and students will have a push effect on academics to adopt the technology. Our study goes some way in understanding the adoption of e-books by academics and also highlights further issues that need to be addressed such as integration of video-slide modules, interactive programs for textual analyses, multimedia enhancements that can be dynamically manipulated (Landau, Paez, Bordeianu, \& Haerer, 2011).

The results presented in this study are consistent with the previous research of TTF. Importantly that users’ perception of the TTF of e-books and utilization explain a significant amount of the variance of perceived performance. What is salient in this study is the very strong relationship between utilization and perceived performance; much stronger than that between TTF and performance. This may suggest that actual usage of ebooks may not be dependent on perception of fit (with fit only explaining $7 \%$ of the variation of utilization). Rather than fit being a factor of adoption perhaps academics, having a wide experience of using content online, 
are adept at using content in an electronic context and thus familiar with the functionality of e-readers and the affordances they offer.

This study is constrained by some limitations. The reliance on Shelburne (2009) and Gray and Byrne (2011) as the two sources providing the artifacts of perception of the affordances of e-books may have limited the number of dimensions of the TTF construct. The variance explained of the TTF construct is low, $18 \%$. This is strong evidence indicating that not all dimensions of fit may have been identified in this study. Perhaps this could be addressed by further qualitative approaches such as focus groups to enable identification of additional dimensions of TTF. Further the output factor is composed of two items only, bringing into question the veracity of the factor as a scale in any future research. We suggest that further work be undertaken to increase the number of items in the output factor. The sample of the study is limited to academics of a large Australian university that has no strategy for the adoption of e-books by staff or students, but had subscriptions to about 200,000 e-books in 2011. Any future work should make use of a broader sample including academics from an environment where strategies are in place for the use and adoption of e-books. Such university environments would have libraries owning or subscribing to over 500,000 (and rising) e-books.

\section{Acknowledgements}

We thank Robyn Drummond, Pam Freeland, and Janet Fletcher of the University of New South Wales Library for their assistance in the design, development, implementation, and analysis of the survey; we are grateful to those UNSW academics from the Faculties of Medicine, Science, and Engineering who completed the online survey; and we acknowledge financial support from the John Metcalfe Memorial Fund.

\section{References}

Ajzen, I. (1991). The theory of planned behavior. Organizational Behavior and Human Decision Process, 50, $179-211$.

Anuradha, K.T., \& Usha, H.S. (2006). Use of e-books in an academic and research environment: A case study from the Indian Institute of Science. Electronic Library and Information Systems, 40 (1), 48-62.

Barki, H., Titah, R., \& Boffo, C. (2007). Information systems use - related activity: An expanded behavioural expansion conceptualtization of individual-level information system use. Information Systems Research, 18 (2), 173-192. 
Bandura, A. (1986). Social foundations of thought and action: A social cognitive theory. Englewood Cliffs, NJ: Prentice-Hall.

Belanger, F., Collins, R.W., \& Cheney, P.H. (2001). Technology requirements and work group communications for telecommuters. Information Systems Research, 12(2), 155-176.

Benbasat, I., \& Barki, H. (2007). Quo Vadis; TAM? Journal of the Association for Information Systems, 8(4), $211-218$.

Bennett, L., \& Landoni, M. (2005). E-books in academic libraries. The Electronic Library, 23(1), 9-16.

Bhattacharjee, S., Gopal R.D., Marsden J.R., \& Sankaranarayanan, R. (2011). Digital goods and markets: Emerging issues and challenges. ACM Transactions on Management Information Systems, 2 (2), 8:1-8:13. Bierman, J., Ortega, L., \& Rupp-Serrano, K. (2010). E-book usage in pure and applied sciences. Science \& Technology Libraries, 29 (1-2), 69-91.

Carswell, L., Thomas, P., Petre, M., Price, B., \& Richards, M. (2000). Distance education via the Internet: The student experience. British Journal of Educational Technology, 31 (1), 29-46.

Carswell, A.D., \& Venkatesh, V. (2002). Learner outputs in an asynchronous distance education environment. International Journal of Human-Computer Studies, 56 (5), 475-494.

Cheng, T.C, Lam, D. \& Yeung, A. ( 2006). Adoption of internet banking: An empirical study in Hong Kong, Decision Support Systems, 42, 1558-1572.

Chin, W.W. (1998). The Partial Least Squares approach to structural equation modeling. In: G.A. Marcoulides (Ed.), Modern Business Research Methods (pp. 295-336), Mahwah, NJ: Lawrence Erlbaum Associates. Chin, W.W. (2001). PLS - Graph user’s guide version 3.0. Houston, TX: Soft Modeling Inc.

Chin, W.W. (2010). How to write up and report PLS analyses. In: V. Esposito Vinzi, W.W. Chin, J. Henseler, \& H. Wang (Eds.), Handbook of Partial Least Squares: Concepts, methods and application. (pp. 645-689), Germany: Springer.

Cho, V. (2006). A study of the roles of trusts and risks in information-oriented online legal services using an integrated model. Information \&Management, 43 (4), 502-520.

Cox, L. (2010). Scholarly book publishing practice: The ALPSP survey findings. Learned Publishing, 23 (4), 347-356.

D’Ambra, J., \& Rice, R.E. (2001). Emerging factors in user evaluation of the world wide web. Information and Management, 38, 373-384. 
D’Ambra, J., \& Wilson, C.S. (2004). Use of the world wide web for international travel: Integrating the construct of uncertainty in information seeking and the task-technology fit model. Journal of the American Society for Information Science and Technology, 55 (8), 731-742.

Davis, F.D. (1989). Perceived usefulness, perceived ease of use, and user acceptance of information technology. MIS Quarterly, 13 (3), 319-340.

Dishaw, M.T., \& Strong, D.M. (1998). Supporting software maintenance with software engineering tools: A computed task-technology fit analysis. The Journal of Systems and Software, 44(2), 107-120.

Dishaw, M.T., \& Strong, D.M. (1999). Extending the technology acceptance model with task-technology fit constructs. Information \& Management, 36 (1), 9-21.

Dishaw, M.T., \& Strong, D.M. (2003). The effect of task and tool experience on maintenance CASE Tool usage. Information Resources Management Journal, 16 (3), 1-16.

Efron, B., \& Tibshirani, R. J. (1993). An introduction to the bootstrap. New York: Chapman and Hall.

Fishbein, M. \& Ajzen, I. (1975). Belief, attitude, intention, and behavior: An introduction to theory and research. Reading,,MA.: Addison-Wesley.

Foote, J.B., \& Rupp-Serrano K. (2010). Exploring e-book usage among faculty and graduate students in the geosciences: Results of a small survey and focus group approach. Science and Technology Libraries, 29 (3), 216-234.

Fuller, R.M., \& Dennis, A.R. (2009). Does fit matter? The impact of task-technology fit and appropriation on team performance in repeated tasks. Information Systems Research, 20 (1), 2-17.

Gray, R., \& Byrne, K. (2011). Space oddity: Contemporary concepts of content for academic libraries. In: Proceedings of the Third International m-libraries Conference, May 11-13, 2011, Brisbane Australia.

Goodhue, D.L. (1995). Understanding user evaluations of information systems. Management Science, 41(12), 1827-1844.

Goodhue, D.L. (1998). Development and measurement validity of a task-technology fit instrument for user evaluations of information systems. Decision Sciences, 29 (1), 105-138.

Goodhue, D.L., Klein, B.D., \& March, S. T. (2000). User evaluations of IS as surrogates for objective performance. Information \& Management, 38, 87-101.

Goodhue, D.L., Littlefield, R., \& Straub, D. (1997). The measurement of the impacts of the IIC on the endusers: The survey. Journal of the American Society for Information Science, 48 (5), 454-465. 
Goodhue, D.L, \& Thompson, R.L. (1995). Task-technology fit and individual performance. MIS Quarterly, 19 (2), 213-236.

Gwebu, K.L. \& Wang, J. (2011). Adoption of open source software: The role of social identification. Decision Support Systems, 5 (1), 220-229.

Ha, S. \& Stoel, L. (2009). Consumer e-shopping acceptance: Antecedents in a technology acceptance model. Journal of Business Research, 62 (5), 565-571.

Jamali, H.R., Nicholas D., \& Rowlands, I. (2009). Scholarly e-books: The views of 16,000 academics. Aslib Proceedings, 61 (1), 33-47.

Junglas, I., Abraham, C., \& Watson, R. T. (2008). Task-technology fit for mobile locatable information systems. Decision Support Systems, 45 (4), 1046-1057.

Keller, A. (2012). In print or on screen? Investigating the reading habits of undergraduate students using photodiaries and photo-interviews. Libri, 62, 1-18,

Kim, S.S., \& Malhotra, N.K. (2005). A longitudinal model of continued IS use: An integrative view of four mechanisms underlying post-adoption phenomena. Management Sciences, 51 (5), 741-755.

King, W.R. \& He, J. (2006). A meta-analysis of the technology acceptance model. Information \& Management, 43 (6), 740-755.

Kwon, O. \& Wen, Y. (2010). An empirical study of the factors affecting social network service use. Computers in Human Behavior, 26 ( 2), 254-263.

Landau, R.H., Paez, M.J., Bordeianu, C., \& Haerer, S. (2011). Making physics education more relevant and accessible via computation and etextbooks. Computer Physics Communications, 182 (9), 2071-2075.

Lee, C., Cheng, H.K., \& Cheng, H-H. (2007). An empirical study of mobile commerce in insurance industry: Task-technology fit and individual differences. Decision Support Systems, 43 (1), 95-110.

Lee, H., Jeun, I., \& Jung, H. (2009). Criteria for evaluating the privacy protection level of Identity Management Services. The Third International Conference on Emerging Security Information, Systems and Technologies, 150-160.

Library Journal. (2011). Ebook Penetration \& Use in U.S. Academic Libraries. Second Annual Survey. New York: Library Journal.

Mallat, N. (2007). Exploring consumer adoption of mobile payments - A qualitative study. Journal of Strategic Information Systems, 16 (4), 413-432. 
McClanahan, K., Wu, L., Tenopir, C., \& King, D.W. (2010). Embracing change: Perceptions of e-journals by faculty members. Learned Publishing, 23 (3), 209-223.

McGill, T.J., \& Klobas, J.E. (2009). A task-technology fit view of learning management system impact. Computers \& Education, 52 (2), 496-508.

McGill, T.J., Klobas, J.E., \& Renzi, S. (2011). LMS use and instructor performance: The Role of Tasktechnology fit. International Journal on E-Learning, 10(1), 43-62.

Moore, G. \& Benbasat, I. (1991). Development of an instrument to measure perceptions of adopting an information technology innovation. Information Systems Research, 2 (3), 192-222.

Nan, N. (2011). Capturing bottom-up information technology use processes: A complex adaptive systems model. MIS Quarterly, 35 (2), 505-532.

Ngai, E.W.T., Poon, J., \& Chan, T.H.C. (2007). Empirical examination of the adoption of WebCT using TAM. Computers \& Education, 48 (2), 250-267.

Nicholas, D., Rowlands, I., \& Jamali, H.R. (2010). E-textbook use, information seeking behaviour and its impact: Case study business and management. Journal of Information Science, 36 (2), 263-280.

Nicholas, D., Williams, P., Rowlands, I., \& Jamali, H.R. (2010). Researchers' e-journal use and information seeking behaviour. Journal of Information Science, 36 (4), 494-516.

Raven, A., Leeds, E., \& Park, C.W. (2010). Digital video presentation and student performance: A task technology fit perspective. International Journal of Information and Communication Technology Education, $6(1), 17-29$.

Rogers, E.M. (1983). Diffusion of innovations. $3^{\text {rd }}$ ed. New York: Free Press.

Rogers, E.M. (1995). Diffusion of innovations. $4^{\text {th }}$ ed. New York: Free Press.

Schierz, P., Schilke, O. \& Wirtz, B. (2010). Understanding consumer acceptance of mobile payment services: An empirical analysis. Electronic Commerce Research and Applications, 9 (3), 209-216.

Shelburne, W.A. (2009). E-book usage in an academic library: User attitudes and behaviors. Library Collections, Acquisitions, \& Technical Services, 33 (2-3), 59-72.

Shirani, A.I., Tafti, M.H.A., \& Affisco, J.F. (1999). Task and technology fit: A comparison of two technologies for synchronous and asynchronous group communication. Information \& Management, 36 (3), 139-150. Staples, D.S., \& Seddon, P. (2004). Testing the technology-to-performance chain model. Journal of Organizational and End User Computing, 16 (4), 17-36. 
Straub, D., Boudreau, M.C., \& Gefen, D. (2004). Validation guidelines for IS positivist research. Communications of AIS, 13 (24), 380-427.

Tenenhaus, M., Vinzi, V.E., Chatelin, Y.-M., \& Lauro, C. (2005). PLS path modeling. Computational Statistics and Data Analysis, 48 (1), 159-205.

Torkzadeh, G., \& Doll, W.J. (1999). The development of a tool for measuring the perceived impact of information technology on work. OMEGA-International Journal of Management Science, 27 (3), 327-339.

Venkatesh, V. \& Davis, F.D. ( 2000). A theoretical extension of the technology acceptance model: Four longitudinal field studies. Management Science, 46 (2), 186-204.

Venkatesh, V., Morris, M.G., Davis, G.B., \& Davis, F.D. (2003). User acceptance of information technology: Toward a unified view. MIS Quarterly, 27 (3), 425-478.

Vijayasarathy, L. (2004). Predicting consumer intentions to use on-line shopping: the case for an augmented technology acceptance model. Information \& Management, 41 (6), 747-762.

Wenger, J.L. \& Carlson, R.A. (1995). Learning and coordination of sequential information. Journal of Experimental Psychology: Human Perception and Performance, 21 (1), 170-182.

Wetzels, M., Odekerken-Schroder, G , \& van Oppen, C. (2009). Using PLS path modeling for assessing hierarchical construct models: Guidelines and empirical illustration. MIS Quarterly, 33(1), 177-195.

Williams, M.D., Dwivedi, Y.K., Lal, B. \& Schwarz, A. ( 2009). Contemporary trends and issues in IT adoption and diffusion research. Journal of Information Technology, 24 (1), 1-10.

Woody, W.D., Daniel, D.B., \& Baker, C.A. (2010). E-books or textbooks: Students prefer textbooks. Computers \& Education, 55 (3), 945-948.

Zhou, T., Lu, Y., \& Wang, B. (2010). Integrating TTF and UTAUT to explain mobile banking user adoption. Computers in Human Behavior; 26 (4), 760-767.

Zigurs, I., \& Buckland, B.K. (1998). A theory of task/technology fit and group support systems effectiveness. MIS Quarterly, 22 (3), 313-334.

Zigurs, I., Buckland, B.K, Connolly, J., \& Wilson, E.V. (1999). A test of task-technology fit theory for group support systems. Data Base for Advances in Information Systems, 30 (3-4), 34-50.

Zigurs, I., \& Khazanchi, D. (2008). From profiles to patterns: A new view of task-technology fit. Information Systems Management, 25 (1), 8-13. 
TABLE 1. Summary of relevant research on e-books in academic environments.

\begin{tabular}{|c|c|c|c|c|c|}
\hline Study & Focus & $\begin{array}{c}\text { Approach } \\
\text { (Methodology) }\end{array}$ & $\begin{array}{c}\text { Unit of } \\
\text { analysis }\end{array}$ & $\begin{array}{c}\text { Sample } \\
\text { size }\end{array}$ & Findings \\
\hline $\begin{array}{l}\text { Bennett and } \\
\text { Landoni } \\
\text { (2005) }\end{array}$ & $\begin{array}{l}\text { Potential of } \\
\text { e-books in } \\
\text { higher } \\
\text { education }\end{array}$ & $\begin{array}{l}\text { Meta-analysis } \\
\text { of JISC } 2003 \\
\text { Study }\end{array}$ & $\begin{array}{l}\text { Potential e- } \\
\text { books users }\end{array}$ & $\begin{array}{l}24 \text { Univ. } \\
\text { faculty; } \\
20 \text { Further } \\
\text { Education } \\
\text { lecturers; } \\
28 \text { students }\end{array}$ & $\begin{array}{l}\text { Awareness of e-books was low despite holdings of e-book } \\
\text { institutions' libraries being high. Librarians play significal } \\
\text { in increasing awareness and training both academics and } \\
\text { students. }\end{array}$ \\
\hline $\begin{array}{l}\text { Anuradha } \\
\text { and Usha } \\
\text { (2006) }\end{array}$ & $\begin{array}{l}\text { Use and } \\
\text { usability of } \\
\text { e-books }\end{array}$ & $\begin{array}{l}\text { Quantitative - } \\
\text { descriptive }\end{array}$ & $\begin{array}{l}\text { Faculty and } \\
\text { students }\end{array}$ & 101 & $\begin{array}{l}\text { Usage of e-books was low. Those who did use e-books us } \\
\text { them mostly for reference and technical material. }\end{array}$ \\
\hline $\begin{array}{l}\text { Jamali, } \\
\text { Nicholas \& } \\
\text { Rowlands } \\
\text { (2009) }\end{array}$ & $\begin{array}{l}\text { Perspective } \\
\text { of students } \\
\text { and } \\
\text { academics of } \\
\text { e-books. }\end{array}$ & $\begin{array}{l}\text { Qualitative - } \\
\text { advantages, } \\
\text { disadvantages } \\
\text { of e-books; } \\
\text { Other data on } \\
\text { the use of e- } \\
\text { books }\end{array}$ & $\begin{array}{l}\text { Faculty and } \\
\text { students }\end{array}$ & 20,000 & $\begin{array}{l}\text { Convenience of e-books associated with on-line access alc } \\
\text { with searchability as the greatest advantage of e-books. e- } \\
\text { yet to become more student friendly. }\end{array}$ \\
\hline $\begin{array}{l}\text { Shelburne } \\
\text { (2009) }\end{array}$ & $\begin{array}{l}\text { Usage } \\
\text { patterns and } \\
\text { library } \\
\text { patron } \\
\text { attitudes to } \\
\text { e-books }\end{array}$ & $\begin{array}{l}\text { Quantitative - } \\
\text { descriptive } \\
\text { Awareness and } \\
\text { usage of e- } \\
\text { books; } \\
\text { advantages and } \\
\text { disadvantages }\end{array}$ & $\begin{array}{l}\text { Faculty and } \\
\text { students }\end{array}$ & 1,547 & $\begin{array}{l}\text { Awareness and attitudes presented for: faculty, graduate } \mathrm{s} 1 \\
\text { and undergraduate students. }\end{array}$ \\
\hline $\begin{array}{l}\text { Berg, } \\
\text { Hoffman \& } \\
\text { Dawson } \\
(2010)\end{array}$ & $\begin{array}{l}\text { Use of e- } \\
\text { books and } \\
\text { print books } \\
\text { for } \\
\text { information } \\
\text { retreival }\end{array}$ & $\begin{array}{l}\text { Usability study } \\
\text { - think-aloud } \\
\text { method and } \\
\text { qualitative } \\
\text { analysis }\end{array}$ & Students & 20 & $\begin{array}{l}\text { Students in the study appeared to understand the conventic } \\
\text { print books for satisfying information seeking; however th } \\
\text { were unclear about the structure and functionality of e-boc }\end{array}$ \\
\hline $\begin{array}{l}\text { Bierman, } \\
\text { Ortega \& } \\
\text { Rupp- } \\
\text { Serrano } \\
\text { (2010) }\end{array}$ & $\begin{array}{l}\text { Preference } \\
\text { for e-books } \\
\text { within a } \\
\text { specific } \\
\text { discipline } \\
\text { domain }\end{array}$ & $\begin{array}{l}\text { Quantitative } \\
\text { (descriptive) } \\
\text { and qualitative } \\
\text { - usage and } \\
\text { usablity }\end{array}$ & Faculty & 11 & $\begin{array}{l}\text { Previous usage of e-books was low. Advantages and } \\
\text { disadvantages identified after usage of an e-book were: } \\
\text { Ease of access; searchability; highlighting and annotating; } \\
\text { and paste; portability (advantages). Ergonomic concerns o } \\
\text { e-books of desktops and laptops; inability to absorb inforl } \\
\text { from reading an e-book; difficulty to quickly assess and er } \\
\text { quality; reliability on external provider for access to e-boo } \\
\text { (disadvantages). }\end{array}$ \\
\hline $\begin{array}{l}\text { Foote \& } \\
\text { Rupp- } \\
\text { Serrano } \\
(2010)\end{array}$ & $\begin{array}{l}\text { Preference } \\
\text { for e-books } \\
\text { within a } \\
\text { specific } \\
\text { discipline } \\
\text { domain } \\
\end{array}$ & $\begin{array}{l}\text { Qualitative } \\
\text { (descriptive) } \\
\text { and qualitative } \\
\text { - usage and } \\
\text { usability of e- } \\
\text { books }\end{array}$ & $\begin{array}{l}\text { Faculty and } \\
\text { students }\end{array}$ & 18 & $\begin{array}{l}\text { Usage of e-books varied between faculty and students. Is } \\
\text { that effected usage were: ability to download entire e-bool } \\
\text { searchability; the use of graphics. }\end{array}$ \\
\hline $\begin{array}{l}\text { Nicholas, } \\
\text { Rowlands } \\
\text { \& Jamali } \\
(2010)\end{array}$ & $\begin{array}{l}\text { e-book usage } \\
\text { and } \\
\text { information } \\
\text { seeking } \\
\text { behaviour of } \\
\text { business and } \\
\text { management } \\
\text { students }\end{array}$ & $\begin{array}{l}\text { Quantitative } \\
\text { (descriptive: } \\
\text { deep log } \\
\text { analysis; } \\
\text { questionnaire; } \\
\text { focus groups) }\end{array}$ & $\begin{array}{l}\text { Faculty and } \\
\text { students }\end{array}$ & 5000 & $\begin{array}{l}\text { Business students are major and significant users of e-boo } \\
\text { e-textbooks; factors contributing to high use are: e-books } \\
\text { attractive to university users; nature of business studies mı } \\
\text { that e-books are especially attractive; staff and librarians } \\
\text { promote them more; there is a large number of manageme } \\
\text { business students. }\end{array}$ \\
\hline $\begin{array}{l}\text { Woody, } \\
\text { Daniel \& } \\
\text { Baker } \\
(2010)\end{array}$ & $\begin{array}{l}\text { Factors } \\
\text { influencing } \\
\text { preference } \\
\text { for e-books } \\
\text { as well as } \\
\text { reported use } \\
\text { of e-book } \\
\text { content }\end{array}$ & $\begin{array}{l}\text { Quantitative } \\
\text { (descriptive) - } \\
\text { usage and } \\
\text { preference for } \\
\text { e-books. }\end{array}$ & Students & 91 & $\begin{array}{l}\text { Students did not prefer e-textbooks to print textbooks; no } \\
\text { significant correlation between previous use of e-textbook } \\
\text { overall preference for e-textbooks. Students were more lik } \\
\text { use special features in print books than e-textbooks. }\end{array}$ \\
\hline $\begin{array}{l}\text { Foasberg } \\
\text { (2011) }\end{array}$ & $\begin{array}{l}\text { e-reader } \\
\text { ownership } \\
\text { and reading } \\
\text { e-books on } \\
\text { e-readers }\end{array}$ & $\begin{array}{l}\text { Quantitative } \\
\text { (descriptive) }\end{array}$ & Students & 1705 & $\begin{array}{l}\text { In terms of e-readers uptake is low. Students who own e-rr } \\
\text { use them primarily for leisure reading and continue to rely } \\
\text { print for much of their reading. Price was identified as a } \\
\text { to adoption and students had little interest in borrowing e- } \\
\text { from the library. }\end{array}$ \\
\hline
\end{tabular}




\begin{tabular}{|l|l|l|l|l|l|}
\hline $\begin{array}{l}\text { Library } \\
\text { (2011) }\end{array}$ & $\begin{array}{l}\text { Peneration } \\
\text { and use of e- } \\
\text { books in } \\
\text { U.S. } \\
\text { academic } \\
\text { libraries }\end{array}$ & $\begin{array}{l}\text { Quantitative } \\
\text { (descriptive); } \\
\text { qualitative } \\
\text { (open-ended } \\
\text { comments) }\end{array}$ & Libraries & 488 & $\begin{array}{l}\text { 95\% offered e-books; average e-book collection nearly double } \\
\text { since 2010; nearly 60\% experienced increased demand for e- } \\
\text { books; and c.58\% stated that barrier to use of e-books was due to } \\
\text { 'non-awareness'. }\end{array}$ \\
\hline $\begin{array}{l}\text { Keller } \\
(2012)\end{array}$ & $\begin{array}{l}\text { Explores } \\
\text { decision } \\
\text { making } \\
\text { process that } \\
\text { students } \\
\text { engage in } \\
\text { when } \\
\text { choosing to } \\
\text { read texts 'in } \\
\text { print or on } \\
\text { screen'. }\end{array}$ & $\begin{array}{l}\text { Quantitative - } \\
\text { descriptive } \\
\text { (photo-diaries); } \\
\text { Qualitative } \\
\text { (photo- } \\
\text { elicitation } \\
\text { interviews) }\end{array}$ & Students & 12 & $\begin{array}{l}\text { Distraction caused by computers when reading on screen is a } \\
\text { significant disadvantage. }\end{array}$ \\
& & & & \\
\hline
\end{tabular}

TABLE 2. Theories used in individual and organizational information technology (IT) adoption research.

\begin{tabular}{llcc}
\hline Theory & Author(s) & $\begin{array}{l}\text { Used in } \\
\text { individual } \\
\text { adoption } \\
\text { studies }\end{array}$ & $\begin{array}{l}\text { Used in } \\
\text { organizational } \\
\text { adoption } \\
\text { studies }\end{array}$ \\
\hline Innovation Diffusion Theory (IDT) & Rogers (1983, 1995) & $\mathrm{X}$ & $\mathrm{X}$ \\
Perceived Characteristics of Innovations & $\begin{array}{l}\text { Moore and Benbasat } \\
(1991)\end{array}$ & $\mathrm{X}$ & $\mathrm{X}$ \\
Social Cognitive Theory (SCT) & Bandura (1986) & $\mathrm{X}$ \\
Technology Acceptance Model (TAM) & Davis (1989) & $\mathrm{X}$ \\
Technology Acceptance Model II (TAM2) & Venkatesh et al. (2000) & $\mathrm{X}$ \\
Theory of Planned Behaviour (TPB) & Ajzen (1991) & $\mathrm{X}$ \\
Task-Technology Fit (TTF)* & Goodhue and & $\mathrm{X}$ \\
Theory of Reasoned Action (TRA) & $\begin{array}{l}\text { Fishbein and Ajzen } \\
\text { (1975) }\end{array}$ & $\mathrm{X}$ \\
Unified Theory of Acceptance and Use of & Venkatesh et al. (2003) & & \\
Technology (UTAUT) & & &
\end{tabular}


TABLE 3. Research model for task-technology fit of e-books in academic settings.

\begin{tabular}{|c|c|}
\hline Task & $\begin{array}{l}\text { - } \quad \text { I use e-books to prepare lecture notes } \\
\text { - } \quad \text { I use e-books to check facts } \\
\text { - } \quad \text { I use e-books as textbooks } \\
\text { - } \quad \text { I use e-books for researching a topic } \\
\text { - } \quad \text { I use e-books to create reference lists/reading list/bibliographies }\end{array}$ \\
\hline Technology - Platform & $\begin{array}{l}\text { What physical characteristics would be important to you in a physical device } \\
\text { (select more than 1): } \\
\text { - Weight } \\
\text { - Battery life } \\
\text { - Screall size } \\
\text { - } \quad \text { Low glare } \\
\text { - Storage capacity } \\
\text { - Ability to adjust lighting }\end{array}$ \\
\hline Technology - Content & $\begin{array}{l}\text { I would be more likely to use a portable reading device if I could ... } \\
\text { - } \text { Adjust font size } \\
\text { - } \text { Turn pages } \\
\text { - } \\
\text { - } \\
\text { Download content to the device easily } \\
\text { Organize collections of e-books (bookshelf) }\end{array}$ \\
\hline Individual & $\begin{array}{l}\text { - Years of experience accessing electronic resources online } \\
\text { - How would you rate the competency in using computer technology }\end{array}$ \\
\hline TTF (Task-technology fit) & $\begin{array}{l}\text { Within an e-book I would like to be able to: } \\
\text { - } \text { bookmark } \\
\text { - } \text { annotate } \\
\text { - } \text { highlight } \\
\text { - } \text { browse table of contents } \\
\text { - } \text { link from indices to text } \\
\text { - } \text { copy across full text } \\
\text { - have a read-aloud option } \\
\text { - } \text { translate to other language } \\
\text { - } \text { print }\end{array}$ \\
\hline Performance & $\begin{array}{l}\text { - e-books help me to improve the quality of my teaching } \\
\text { - e-books help me to improve the quality of my research } \\
\text { - e-books improve my productivity } \\
\text { - e-books help me to accomplish more work than would otherwise be } \\
\text { possible } \\
\text { e-books help me to perform my job better }\end{array}$ \\
\hline Utilization & $\begin{array}{l}\text { - I currently use e-books for teaching, research, and administrative purposes } \\
\text { - } \quad \text { I prescribe e-books as textbooks } \\
\text { - } \quad \text { I use e-books for comprehensive reading }\end{array}$ \\
\hline
\end{tabular}


TABLE 4. Items developed for task-technology fit constructs in e-book settings.

\begin{tabular}{|c|c|}
\hline Dimension & Items \\
\hline TTF construct & $\begin{array}{l}\text { 1. Within an e-book, I would like to be able to bookmark. } \\
\text { 2. Within an e-book, I would like to be able to annotate. } \\
\text { 3. Within an e-book, I would like to be able to highlight. } \\
\text { 4. Within an e-book, I would like to be able to browse table of contents. } \\
\text { 5. Within an e-book, I would like to be able to browse index. } \\
\text { 6. Within an e-book, I would like to be able to link from indices to text. } \\
\text { 7. Within an e-book, I would like to be able to search across full text. } \\
\text { 8. Within an e-book, I would like to be able to copy. } \\
\text { 9. Within an e-book, I would like to be able to have a read-aloud option } \\
\text { 10. Within an e-book, I would like to be able to view high resolution images. } \\
\text { 11. Within an e-book, I would like to be able to translate to other language. } \\
\text { 12. Within an e-book, I would like to be able to print. }\end{array}$ \\
\hline
\end{tabular}

TABLE 5. Descriptive statistics of survey respondents $(n=361)$.

\begin{tabular}{|c|c|c|}
\hline Variables & Categories & $\begin{array}{c}\text { Statistics } \\
(\%)\end{array}$ \\
\hline Gender & $\begin{array}{l}\text { Male } \\
\text { Female }\end{array}$ & $\begin{array}{l}59.0 \\
41.0\end{array}$ \\
\hline Faculty* & $\begin{array}{l}\text { Medicine } \\
\text { Science } \\
\text { Engineering } \\
\text { Others }\end{array}$ & $\begin{array}{r}62.0 \\
19.7 \\
16.6 \\
1.7\end{array}$ \\
\hline Academic Ranks** & $\begin{array}{l}\text { Professor } \\
\text { Associate Professor } \\
\text { Senior Lecturer } \\
\text { Lecturer } \\
\text { Associate Lecturer } \\
\text { Others }\end{array}$ & $\begin{array}{r}6.4 \\
6.6 \\
23.0 \\
19.4 \\
12.2 \\
32.4\end{array}$ \\
\hline Job Type & $\begin{array}{l}\text { Full Time Academic } \\
\text { Part Time Academic } \\
\text { Sessional Academic } \\
\text { Conjoint } \\
\text { Research Only } \\
\text { Other Academics }\end{array}$ & $\begin{array}{r}37.7 \\
8.3 \\
0.6 \\
25.2 \\
24.9 \\
3.3\end{array}$ \\
\hline
\end{tabular}




\begin{tabular}{|l|l|r|}
\hline & & 31.0 \\
& $0-4$ Years & 15.5 \\
& $5-7$ Years & 26.6 \\
& $8-15$ Years & 26.9 \\
& $>15$ Years & \\
\hline & & 1.4 \\
& None & 14.7 \\
Experience of Using E-Resources & $0-5$ Years & 33.2 \\
& 6-10 Years & 31.9 \\
& $11-15$ Years & 10.5 \\
& $16-20$ Years & 8.3 \\
\hline * Faculty refers to an administrative division comprised broadly of related \\
subject areas at the University of New South Wales. \\
** For equivalent academic ranks in other countries, see entry under Australia \\
and New Zealand at http://en.wikipedia.org/wiki/List_of_academic_ranks . \\
\hline
\end{tabular}

TABLE 6. Results of exploratory factor analysis of 12 TTF constructs.

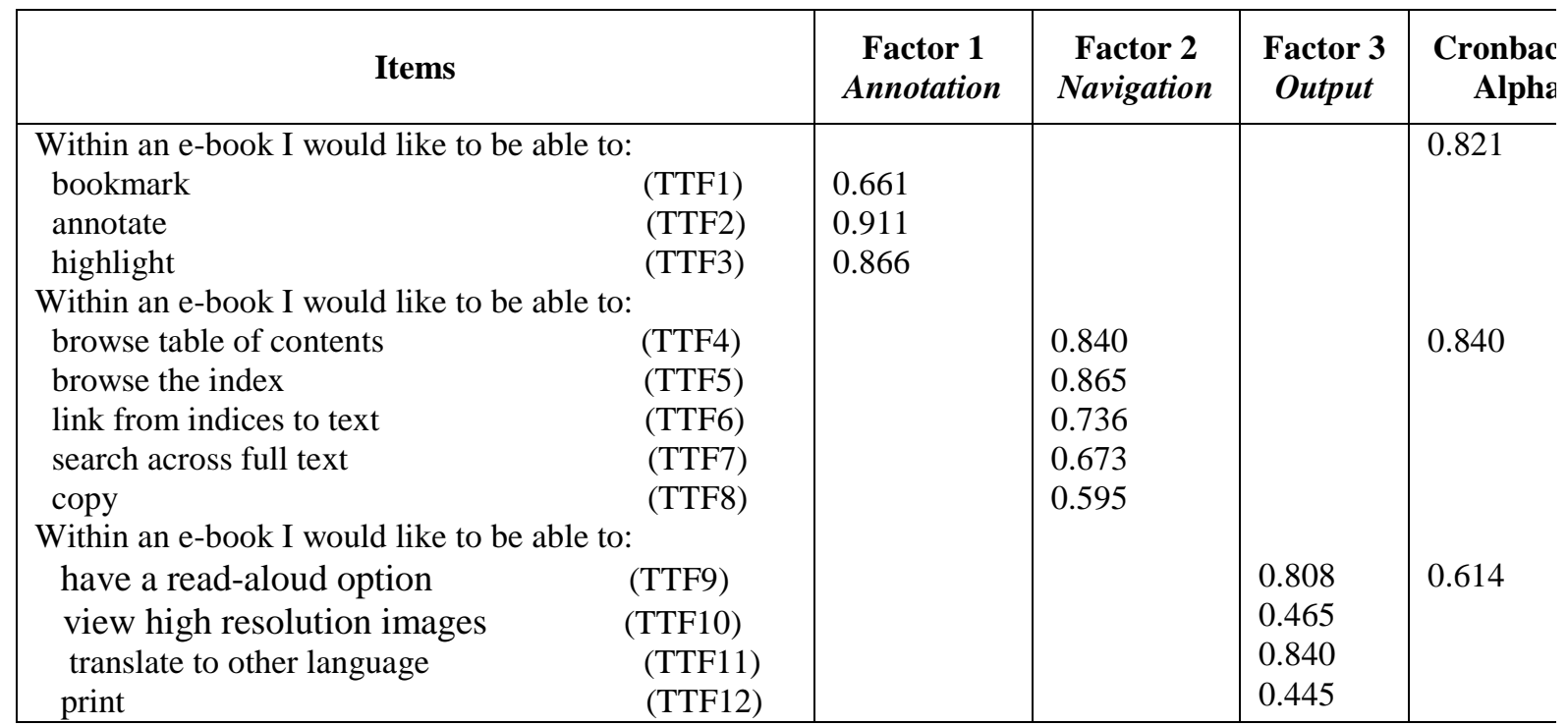


TABLE 7. Results of exploratory factor analysis of 12 TTF constructs with scale refinement.

\begin{tabular}{|c|c|c|c|c|c|c|}
\hline Factor & Items & Loadings & $\begin{array}{l}\text { Item total } \\
\text { correlation }\end{array}$ & Eigenvalue & $\begin{array}{c}\text { Cumulative } \\
\text { Variation }\end{array}$ & $\begin{array}{c}\text { Cronbach's } \\
\text { Alpha }\end{array}$ \\
\hline Annotation & $\begin{array}{l}\text { TTF1 } \\
\text { TTF2 } \\
\text { TTF3 }\end{array}$ & $\begin{array}{l}0.661 \\
0.911 \\
0.866\end{array}$ & $\begin{array}{l}0.540 \\
0.768 \\
0.733\end{array}$ & 4.462 & 26.853 & 0.821 \\
\hline Navigation & $\begin{array}{l}\text { TTF4 } \\
\text { TTF5 } \\
\text { TTF6 } \\
\text { TTF7 } \\
\text { TTF8 }\end{array}$ & $\begin{array}{l}0.840 \\
0.865 \\
0.736 \\
0.673 \\
0.595\end{array}$ & $\begin{array}{l}0.728 \\
0.722 \\
0.630 \\
0.622 \\
0.539\end{array}$ & 1.633 & 19.530 & 0.840 \\
\hline Output & $\begin{array}{l}\text { TTF9 } \\
\text { TTF10* } \\
\text { TTF11 } \\
\text { TTF12* }\end{array}$ & $\begin{array}{l}0.808 \\
0.465 \\
0.840 \\
0.445\end{array}$ & $\begin{array}{l}0.447 \\
0.347 \\
0.509 \\
0.287\end{array}$ & 1.369 & 15.822 & 0.614 \\
\hline
\end{tabular}

TABLE 8. Results of exploratory factor analysis of 10 TTF constructs: Final reliability testing.

\begin{tabular}{|c|c|c|c|c|c|c|}
\hline Factor & Items & Loadings & $\begin{array}{l}\text { Item total } \\
\text { correlation }\end{array}$ & Eigenvalue & $\begin{array}{c}\text { Cumulative } \\
\text { Variation }\end{array}$ & $\begin{array}{c}\text { Cronbach's } \\
\text { Alpha }\end{array}$ \\
\hline Annotation & $\begin{array}{l}\text { TTF1 } \\
\text { TTF2 } \\
\text { TTF3 }\end{array}$ & $\begin{array}{l}0.653 \\
0.916 \\
0.871\end{array}$ & $\begin{array}{l}0.540 \\
0.768 \\
0.733\end{array}$ & 4.083 & 30.679 & 0.821 \\
\hline Navigation & $\begin{array}{l}\text { TTF4 } \\
\text { TTF5 } \\
\text { TTF6 } \\
\text { TTF7 } \\
\text { TTF8 }\end{array}$ & $\begin{array}{l}0.848 \\
0.877 \\
0.764 \\
0.676 \\
0.579\end{array}$ & $\begin{array}{l}0.728 \\
0.722 \\
0.630 \\
0.622 \\
0.539\end{array}$ & 1.532 & 23.117 & 0.840 \\
\hline Output & $\begin{array}{l}\text { TTF9 } \\
\text { TTF11 }\end{array}$ & $\begin{array}{l}0.862 \\
0.865\end{array}$ & $\begin{array}{l}0.523 \\
0.523\end{array}$ & 1.333 & 15.684 & 0.686 \\
\hline
\end{tabular}


TABLE 9. Psychometric properties of the latent variables using confirmatory factor analysis (CFA).

\begin{tabular}{|c|c|c|c|c|c|}
\hline \multicolumn{2}{|c|}{ Latent Variables } & ReflectiveItems & Loadings & CR & AVE \\
\hline \multirow{3}{*}{$\begin{array}{l}\text { Task- } \\
\text { technology } \\
\text { fit (TTF) } \\
(\mathrm{AVE}=0.654) \\
(\mathrm{CR}=0.846)\end{array}$} & Annotation & $\begin{array}{l}\text { Within an e-book, I would like to be able to: } \\
\text { TTF1: Bookmark } \\
\text { TTF2: Annotate } \\
\text { TTF3: Highlight }\end{array}$ & $\begin{array}{l}0.785 \\
0.899 \\
0.887\end{array}$ & 0.893 & 0.737 \\
\hline & Navigation & $\begin{array}{l}\text { Within an e-book, I would like to be able to: } \\
\text { TTF4: Browse table of contents } \\
\text { TTF5: Browse index } \\
\text { TTF6: Link from indices to text } \\
\text { TTF7: Search across full text } \\
\text { TTF8: Copy }\end{array}$ & $\begin{array}{l}0.844 \\
0.837 \\
0.769 \\
0.762 \\
0.706\end{array}$ & 0.889 & 0.617 \\
\hline & Output & $\begin{array}{l}\text { Within an e-book, I would like to be able to: } \\
\text { TTF9: Have a read-aloud option } \\
\text { TTF11: Translate to other language }\end{array}$ & $\begin{array}{l}0.844 \\
0.713\end{array}$ & 0.757 & 0.610 \\
\hline \multicolumn{2}{|c|}{ Task (TAS) } & $\begin{array}{l}\text { TAS1: I use e-books to prepare lecture notes } \\
\text { TAS2: I use e-books to check facts } \\
\text { TAS3: I use e-books for researching a topic } \\
\text { TAS4: I use e-books to create reference } \\
\text { lists/reading lists/bibliographies }\end{array}$ & $\begin{array}{l}0.800 \\
0.901 \\
0.891 \\
0.784\end{array}$ & 0.905 & 0.659 \\
\hline \multicolumn{2}{|c|}{$\begin{array}{l}\text { Performance Impact } \\
\text { (PIM) }\end{array}$} & $\begin{array}{l}\text { PIM1: e-books help me to improve the quality of } \\
\text { my teaching. } \\
\text { PIM2: e-books help me to improve the quality of } \\
\text { my research. } \\
\text { PIM3: e-books help me to improve my } \\
\text { productivity. } \\
\text { PIM4: e-books help me to accomplish more work. } \\
\text { PIM5: e-books help me to perform my job better. }\end{array}$ & $\begin{array}{l}0.818 \\
0.911 \\
0.957 \\
0.931 \\
0.932\end{array}$ & 0.961 & 0.830 \\
\hline \multicolumn{2}{|c|}{ Use (UTL) } & $\begin{array}{l}\text { UTL1: I currently use e-books as text books. } \\
\text { UTL2: I currently use e-books for comprehensive } \\
\text { reading. } \\
\text { UTL3: I currently use e-books for all academic } \\
\text { purposes. }\end{array}$ & $\begin{array}{l}0.761 \\
0.834 \\
0.833\end{array}$ & 0.852 & 0.657 \\
\hline \multicolumn{2}{|c|}{ Latent Variables } & Formative Items & Weights & $\begin{array}{l}\text { t- } \\
\text { value }\end{array}$ & VIF \\
\hline \multirow{2}{*}{ Technology } & $\begin{array}{l}\text { Platform } \\
\text { (TEP) }\end{array}$ & $\begin{array}{l}\text { TEP1: Weight } \\
\text { TEP2: Battery life } \\
\text { TEP3: Overall size } \\
\text { TEP4: Screen size } \\
\text { TEP5: Storage capacity } \\
\text { TEP6: Lighting }\end{array}$ & $\begin{array}{l}0.274 \\
0.246 \\
0.302 \\
0.254 \\
0.322 \\
0.374\end{array}$ & $\begin{array}{l}4.644 \\
4.444 \\
5.561 \\
5.020 \\
5.417 \\
7.564\end{array}$ & $\begin{array}{l}1.095 \\
1.109 \\
1.070 \\
1.235 \\
1.205 \\
1.060\end{array}$ \\
\hline & $\begin{array}{l}\text { Content } \\
\text { (TEC) }\end{array}$ & $\begin{array}{l}\text { TEC1: Adjust font size } \\
\text { TEC2: Turn pages } \\
\text { TEC3: Download content to the device } \\
\text { TEC4: Download content form a variety of sources } \\
\text { (i.e. non-proprietary) } \\
\text { TEC5: Organize collections of e-books } \\
\text { (bookshelf). }\end{array}$ & $\begin{array}{l}0.379 \\
0.347 \\
0.291 \\
0.285 \\
0.280\end{array}$ & $\begin{array}{l}6.592 \\
6.769 \\
4.927 \\
4.805 \\
\\
5.489\end{array}$ & $\begin{array}{l}1.065 \\
1.109 \\
1.050 \\
1.215 \\
1.205\end{array}$ \\
\hline \multicolumn{2}{|c|}{ Individual (IND) } & $\begin{array}{l}\text { IND1: Years of experience in using e-resources } \\
\text { IND2: Level of competency in using computer } \\
\text { technology }\end{array}$ & $\begin{array}{l}0.294 \\
0.367\end{array}$ & $\begin{array}{l}1.896 \\
4.946\end{array}$ & $\begin{array}{l}1.340 \\
1.442\end{array}$ \\
\hline
\end{tabular}


TABLE 10. Correlations of the latent variables.

\begin{tabular}{|l|l|l|l|l|l|l|}
\hline Constructs & Task & Technology & Individual & TTF & Use & Performance \\
\hline Task & $0.812^{*}$ & & & & & \\
\hline Technology & 0.053 & $-* *$ & & & & \\
\hline Individual & 0.210 & 0.054 & $-* *$ & & & \\
\hline TTF & 0.274 & 0.308 & 0.233 & $0.808^{*}$ & & \\
\hline Use & 0.456 & 0.068 & 0.202 & 0.256 & $0.810^{*}$ & \\
\hline Performance & 0.397 & 0.072 & 0.217 & 0.312 & 0.393 & $0.911^{*}$ \\
\hline $\begin{array}{l}\text { *square root of the AVE on the diagonal for reflective constructs } \\
\text { ** Formative constructs }\end{array}$
\end{tabular}

Appendix 1: Path coefficients, standard errors and T-tests.

\begin{tabular}{|c|c|c|c|c|}
\hline & Paths in the research model & $\begin{array}{c}\text { Path } \\
\text { Coefficients }\end{array}$ & $\begin{array}{c}\text { Standard } \\
\text { Errors }\end{array}$ & T-Stats \\
\hline TTF & $\rightarrow$ Annotation & 0.7763 & 0.0301 & 25.7822 \\
\hline TTF & Navigation & 0.9138 & 0.0138 & 66.2533 \\
\hline TTF & $\longrightarrow$ Output & 0.6146 & 0.0521 & 11.7878 \\
\hline Technology & $\longrightarrow \quad$ Platform & 0.8519 & 0.0174 & 48.8530 \\
\hline Technology & $\longrightarrow \quad$ Content & 0.8500 & 0.0170 & 50.0874 \\
\hline Task & $\longrightarrow$ TTF & 0.2231 & 0.0495 & 4.3872 \\
\hline Technology & $\longrightarrow \quad \mathrm{TTF}$ & 0.2863 & 0.0539 & 5.3129 \\
\hline Individual & $\longrightarrow \quad \mathrm{TTF}$ & 0.1619 & 0.0580 & 2.7894 \\
\hline TTF & $\longrightarrow \quad$ Use & 0.2690 & 0.0537 & 5.0073 \\
\hline TTF & $\longrightarrow$ Performance & 0.1381 & 0.0444 & 3.1185 \\
\hline Use & $\longrightarrow$ Performance & 0.6560 & 0.0308 & 21.2820 \\
\hline
\end{tabular}




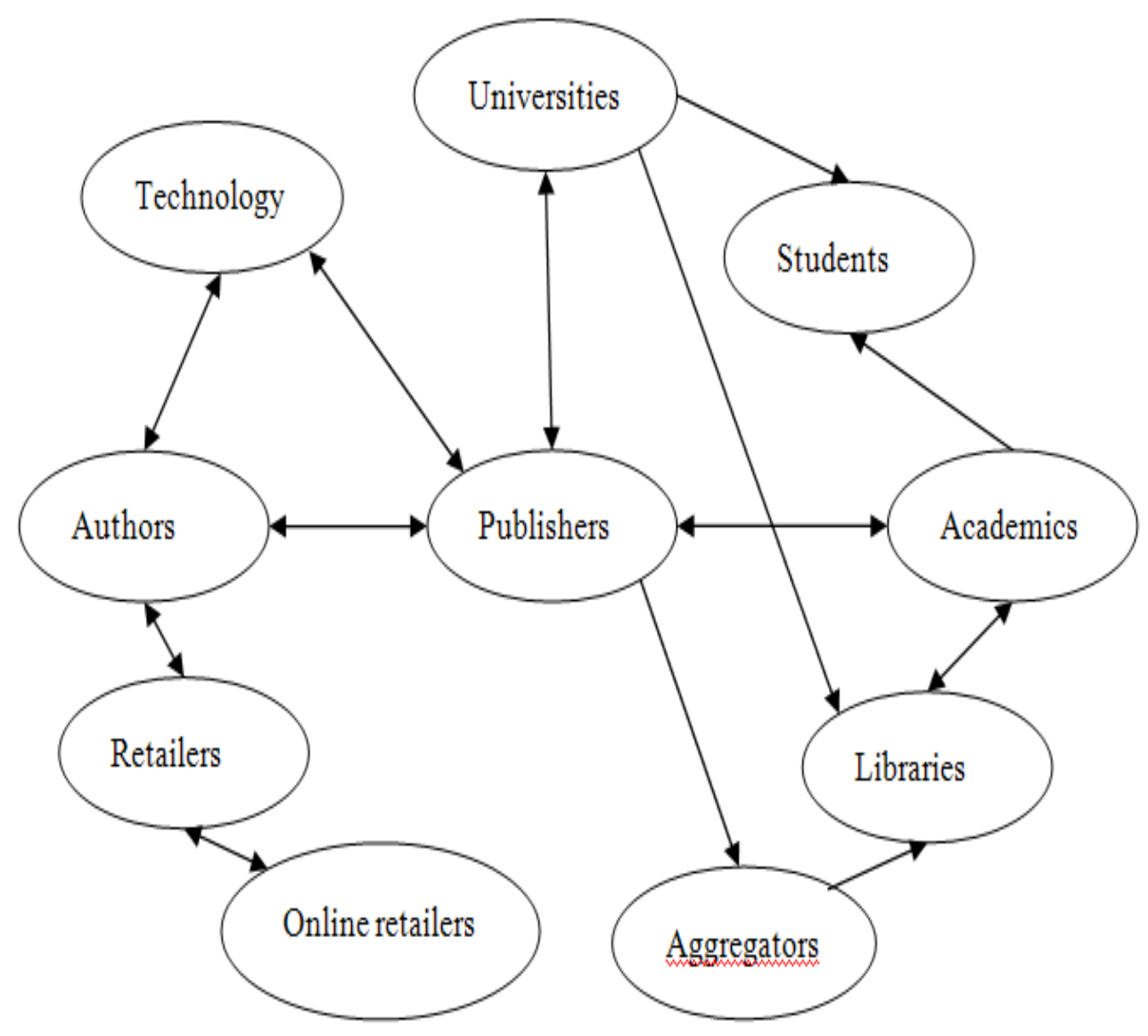

FIG. 1. The emerging e-textbook supply chain. 


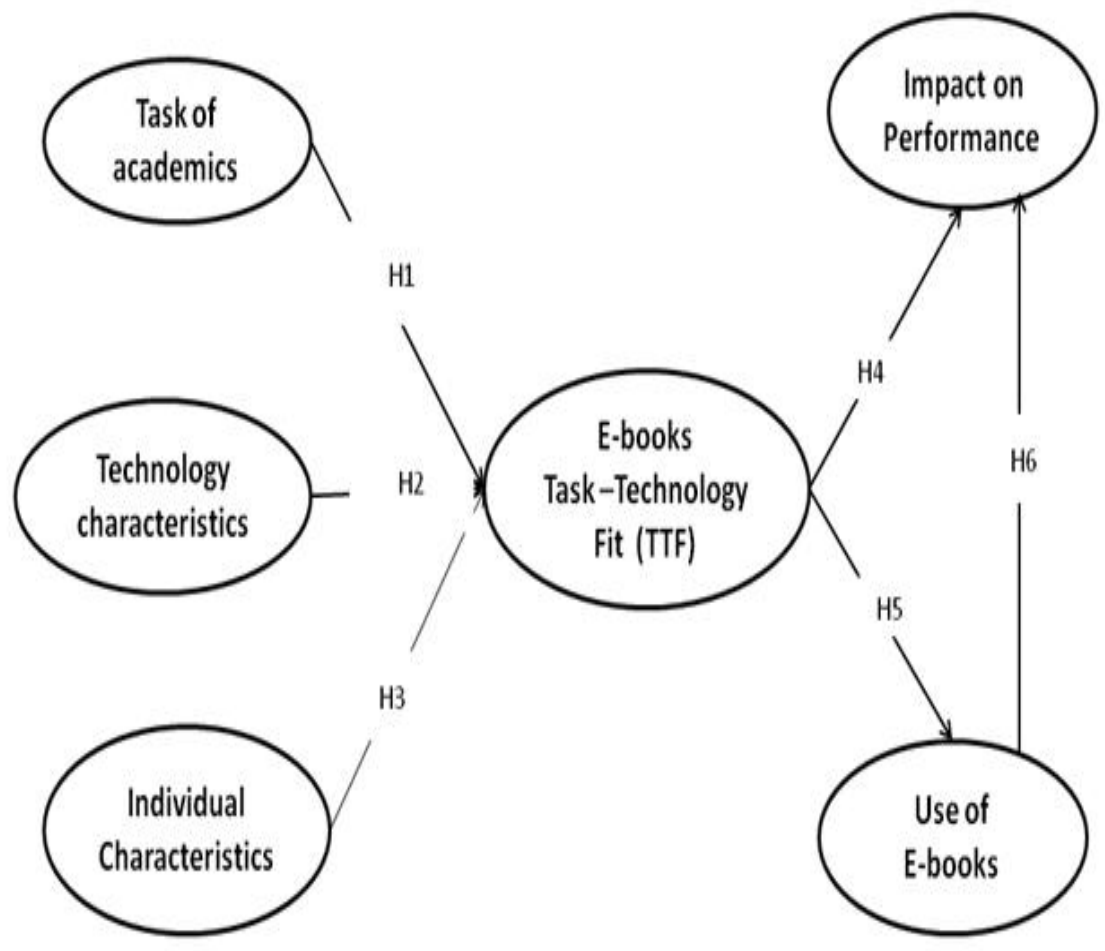

FIG. 2. The task-technology fit (TTF) performance chain. 


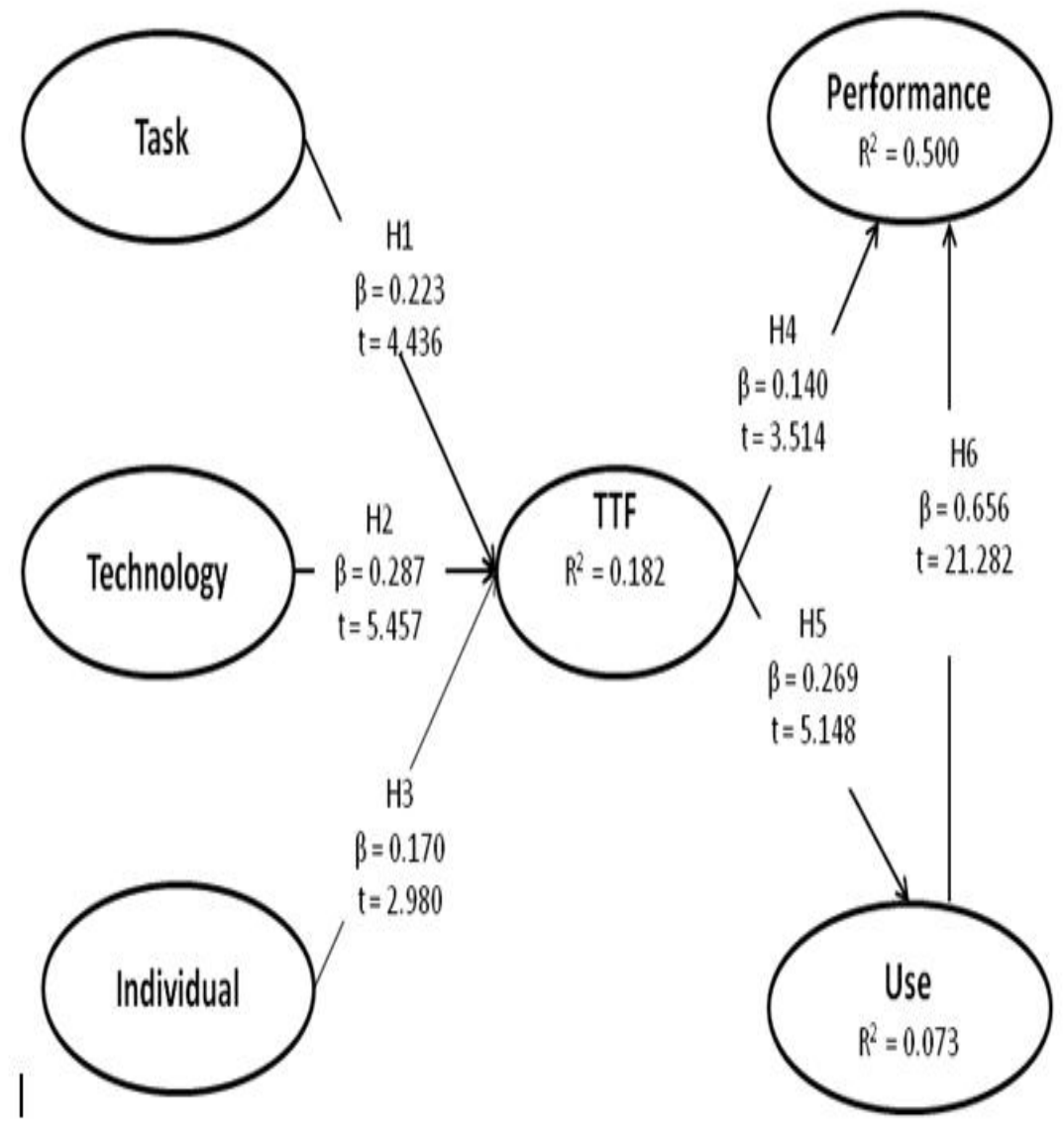

FIG. 3. TTF for e-books in academic settings: Test of hypothesis $(\mathrm{H1}-\mathrm{H} 6)$. 